\title{
Ultimate Load Tests on Bearing Behavior of Large-Diameter Bored Piles in Weathered Rock Foundation
}

\author{
Xiaoyu Bai $\mathbb{i}$, ${ }^{1,2}$ Xueying Liu, ${ }^{1}$ Mingyi Zhang, ${ }^{1,2}$ Yonghong Wang, ${ }^{1,2}$ and Nan Yan $\mathbb{D}^{1,2}$ \\ ${ }^{1}$ Department of Civil Engineering, Qingdao University of Technological, Qingdao, Shandong 266033, China \\ ${ }^{2}$ Cooperative Innovation Center of Engineering Construction and Safety in Shandong Blue Economic Zone, Qingdao, \\ Shandong 266033, China \\ Correspondence should be addressed to Nan Yan; yannan0527@163.com
}

Received 19 May 2020; Revised 25 August 2020; Accepted 29 August 2020; Published 8 September 2020

Academic Editor: Liborio Cavaleri

Copyright $\odot 2020$ Xiaoyu Bai et al. This is an open access article distributed under the Creative Commons Attribution License, which permits unrestricted use, distribution, and reproduction in any medium, provided the original work is properly cited.

Based on the vertical compressive static load test and pile mechanics test of three large diameter bored piles (one of the test piles was treated with postgrouting) in granite gneisses foundation, the bearing capacity, deformation characteristics, and influencing factors of the single pile under the limit state are analyzed and compared with the recommended values of survey report and the recommended values of current codes. By comparing the measured and theoretical values of pile axial force, the bearing capacity of cast-in-place pile under normal and limit conditions is analyzed. The experimental results show that the Q-s curve of large-diameter rock-socketed mud wall retaining bored pile with a length-diameter ratio of 25-33 and rocksocketed depth of 5-8 d shows a rapid growth. After grouting treatment, the ultimate compressive bearing capacity of single pile is improved, the maximum settlement is reduced by $6.6 \%$, the rebound rate is reduced by $11.1 \%$, and the settlement effect of controlling pile top is not significant. The bearing capacity and deformation characteristics of the three test piles are less affected by length-diameter ratio and rock-socketed depth. For postgrouting piles, the ratio of frictional resistance of rocksocketed segment and the ratio of pile lateral resistance are less affected by length-diameter ratio and rock-socketed depth, while, for postgrouting piles, the ratio of pile lateral resistance is more affected by rock-socketed depth. The pile end resistance ratio of the three test piles is significantly affected by the rock-socketed depth, whether or not the pile side postgrouting treatment is carried out.

\section{Introduction}

In recent years, large diameter mud wall protection bored pile $(D \geq 800 \mathrm{~mm})$ has been widely used in pile foundation engineering such as expressway, railway, long-span bridge, and high-rise building, by virtue of its advantages of high bearing capacity, small deformation, convenient construction, etc., shown in engineering practice [1-3]. However, due to the high cost of damage test of rock-socketed cast-in-place pile and the difficulty of complete destructive test, the measured data of systematic and complete static load test are not much, which also restricts the comprehensive study of bearing capacity of rock-socketed cast-in-place pile with large diameter [4-6]. At present, many scholars have carried out a series of related researches on bearing characteristics and load transfer mechanism of cast-in-place pile and obtained beneficial results: Li et al. [7] carried out two fullscale load tests on super-long bored cast-in-place piles, observed their field performance, and proposed a simplified method for nonlinear analysis of load-displacement of single pile. Based on the theoretical and experimental research methods, the bearing characteristics of pile and soil under pile top load are investigated. Omer et al. [8] carried out load tests on large diameter piles on Mercia mudstone foundation and analyzed and evaluated the current design methods of piles under such conditions. Sudheesh et al. [9] explored the load transfer mechanism and influencing factors of postgrouting pile in silty clay by means of test and numerical simulation. Xing et al. [10] conducted on-site installation of optical fiber sensors on the rock-socketed pile of Hezhang bridge with a large diameter. Through the collection, processing, and analysis of test data during the construction of 
super-large rock-socketed piles, the bearing characteristics and load transfer mechanism of super-large rock-socketed piles are discussed. Balakrishnan et al. [11] proposed a reliable method for predicting the load deformation and load distribution curve of bored pile based on the weathering profile and engineering characteristics of the bored pile in a residual regolith (Kenney hill formation) in Kuala Lumpur, as well as the load deformation behavior of fully instrumental test site performance data and load transfer design characteristics. Zhou et al. [12] studied the mechanical performance of pregrouting cast-in-place pile under the action of pressure and tension through field test and threedimensional finite element simulation. Xu et al. [13] explored the construction process of large diameter $(8.0 \mathrm{~m})$ deep hole piles based on the existence of groundwater in bedrock fractures and the location of huge concrete. Zhan et al. [14] confirmed the method based on allowable bearing capacity and lateral resistance of rock socket drill shaft with two test pile structures and tests. Strain gauge and tension rod extensometer are installed in both test piles, and the static compression load test results of the two test piles are given. Seol et al. [15] studied the load transfer method under the axial load of rock-socketed drill shaft. The analysis method of shear load transfer function and load transfer characteristics of rock-socketed wellbore is emphasized. Bai et al. [16] conducted vertical compressive static load test and pile mechanics test for single pile with large diameter mud retaining wall in weathered rock foundation, conducted lateral postgrouting test for 3 test piles, and compared their bearing characteristics, deformation characteristics, and influencing factors with those of nongrouting pile. Chen et al. [17] conducted a full-scale static load test on three bored piles based on the Qingdao area and compared the measured lateral resistance along the rock wall with the prediction results using empirical methods in the literature. It can be seen that the existing relevant research is mainly focused on the super-long drilling or punching in special soil or soft soil foundation, and there are still deficiencies in the research on the ultimate bearing characteristics and failure characteristics of large diameter bored cast-in-place piles treated by postgrouting.

To this end, this paper combined Rizhao proposed building foundation treatment project, the three large diameter bored cast-in-situ concrete piles slurry-supported (including 1 test pile by pile grouting construction technology) for the single pile vertical compressive static load test and pile body mechanics, compared and analyzed their ultimate bearing character, failure behavior, and influencing factors, and compared them with the current specifications and survey report recommended value finishing large diameter side limit of bored cast-in-situ pile side friction resistance, pile size effect coefficient, and enhancing the postgrouting pile side friction coefficient, in order to provide a reference basis for similar projects.

\section{Project Summary}

The test site is a project in the south of Rizhao city. The destruction test of 3 mud retaining wall bored cast-in-place piles TP1 TP3 was carried out, in which TP2 was treated with postgrouting on the side of the pile and the grouting pipe was located at $16.0 \mathrm{~m}$ of the pile. The pile ends of TP1 TP3 are all embedded with fully weathered and strongly weathered granite gneiss. The standard penetration hammer number of each rock is 13.1 and 29.3, respectively, the bearing capacity characteristic value is $250 \mathrm{kPa}$ and $260 \mathrm{kPa}$, respectively, and the compression modulus is $6.5 \mathrm{MPa}$ and $20.0 \mathrm{MPa}$, respectively. The concrete strength of the pile is $\mathrm{C} 30$, the slurry is prepared with $42.5 \#$ ordinary Portland cement, the water-cement ratio is $0.55 \sim 0.70$, the cement consumption of the grouting behind the single pile side of TP2 is $1.5 t$, and the flow is controlled at $40 \sim 50 \mathrm{~L} /$ min. The grouting pressure of weathered rock is $5.0 \mathrm{MPa}$, and that of other soil layers is $2.0 \mathrm{MPa}$. The quality standard of grouting is controlled by a dual-control method, in which the grouting quantity is mainly controlled and the pumping pressure is supplemented. The quality inspection and acceptance of post-pile grouting shall be carried out in accordance with technical code for construction pile foundation (JGJ 94-2008) [18]. The relevant parameters of the test pile are shown in Table 1. The structure of overlying soil layer on the rock foundation is relatively simple, mainly consisting of quaternary mixed fill soil, silty clay, and sandy soil. The average stable groundwater level is about $1.5 \mathrm{~m}$. The physical and mechanical properties of each soil layer are shown in Table 2.

\section{Test Scheme}

3.1. Test Methods. The vertical compressive static load test of a single pile used an anchor pile reaction beam loading device, and its reaction force system should have a safety factor not less than 1.2 times. During the test, the loading and unloading method was carried out with the load maintained at a slow speed, and four displacement sensors were installed symmetrically on the pile top to test the pile top settlement and residual settlement under various loads. Three test piles are loaded in 10 levels, and the first load is 2 levels. When unloading, the unloading value of each level is twice the loading value of each level. The integrity test of low-strain pile body and the vertical compressive static load test of single pile are in strict compliance with the relevant provisions in the technical specification for testing of building foundation piles (JGJ 106-2014) [19]. The experimental process is shown in Figure 1.

3.2. Sensor Layout. Vibrating chord reinforcement stress meter is widely used in the field of engineering stress and strain measurement, to fully understand the stress state of the component under test. It has the advantages of high sensitivity and precision, good linearity and stability, and strong anti-interference ability, and it is waterproof and durable. During the internal force test of the single pile static load test, the sensor adopts a vibrating chord reinforcement stress meter, its model is JTM-V1000, the range is $0 \sim 20 \mathrm{kN}$, and its compressive stress and tensile stress measurement ranges are $100 \mathrm{MPa}$ and $200 \mathrm{MPa}$, respectively. Through the 
TABle 1: Parameters of test piles.

\begin{tabular}{lcccc}
\hline $\begin{array}{l}\text { Test pile } \\
\text { number }\end{array}$ & $\begin{array}{c}\text { Pile diameter } \\
(\mathrm{m})\end{array}$ & $\begin{array}{c}\text { Pile length } \\
(\mathrm{m})\end{array}$ & $\begin{array}{c}\text { Depth of rock-socketed at pile end } \\
(\mathrm{m})\end{array}$ & $\begin{array}{c}\text { Estimated ultimate bearing capacity of single pile } \\
(\mathrm{kN})\end{array}$ \\
\hline TP1 & 1.00 & 25.55 & 5.49 & 15000 \\
TP2 & 0.800 & 25.50 & 5.52 & 9700 \\
TP3 & 0.800 & 26.50 & 6.42 & 9700 \\
\hline
\end{tabular}

TABle 2: Parameters of soils.

\begin{tabular}{lcccccccccc}
\hline Soil layer number and name & $\rho\left(\mathrm{g} / \mathrm{cm}^{3}\right)$ & $W(\%)$ & $G_{s}$ & $e$ & $\rho_{d}\left(\mathrm{~g} / \mathrm{cm}^{3}\right)$ & $I_{L}$ & $\varphi\left({ }^{\circ}\right)$ & $c_{q}(\mathrm{kPa})$ & $\left.\alpha_{0.1-0.2}(\mathrm{MPa})^{-1}\right)$ & $E_{s 0.1-0.2}(\mathrm{MPa})$ \\
\hline (2) -1 Medium-coarse sand & 1.86 & 17.3 & 2.65 & 0.667 & 1.59 & - & 25.5 & 5.30 & 0.09 & 20.5 \\
(5) Medium-coarse sand & 1.97 & 18.6 & 2.65 & 0.596 & 1.66 & - & 24.5 & 5.70 & 0.11 & 15.3 \\
(6) Silty clay & 1.87 & 24.3 & 2.71 & 0.807 & 1.50 & 0.470 & 17.2 & 27.0 & 0.31 & 5.80 \\
(6) Medium-coarse sand & 2.00 & 19.3 & 2.65 & 0.587 & 1.67 & - & 23.9 & 6.00 & 0.09 & 19.9 \\
(7) Residual mucous soil & 1.88 & 27.0 & 2.73 & 0.832 & 1.49 & 0.400 & 15.6 & 30.0 & 0.30 & 6.51 \\
\hline
\end{tabular}

Note: $c$ and $\varphi$ were determined using the quick shear test.

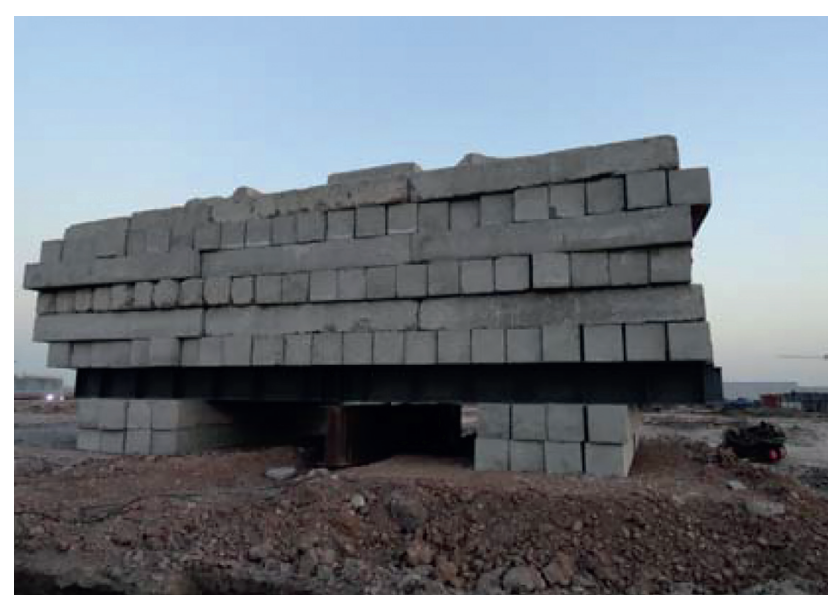

FIgURE 1: Static load test.

form of butt welding and coaxial connection with the main rib of the steel cage, heat insulation measures are taken during welding to prevent damage to the sensor. The test leads are led out of the ground along the whole of the pile body, and they are protected with a soft bandage after being led out. There is no joint in the middle. Avoid using the cable of the steel gauge to lift the steel stress gauge during use. The sensors of the test piles TP $1 \sim$ TP 3 are all located at $2 \mathrm{~m}, 5 \mathrm{~m}$, $8 \mathrm{~m}, 11 \mathrm{~m}, 14 \mathrm{~m}, 17 \mathrm{~m}$, and $19 \mathrm{~m}$ at the pile body. Four steel bar stress gauges are installed on each section, and the angle of the stress gauge is $90^{\circ}$. The sensor distribution is shown in Figure 2.

\section{Calculation Method}

4.1. Calculation Method of Pile Stress Measured Value. Steel bar meter calibration before embedding, in the process of static loading step by step, used the DP-YT-DSY$406 \mathrm{~A}$ frequency of reading meter at the top of the pile displacement test time record of reinforcing steel bar meter readings, namely, initial readings before test and after the test load in the process of reading, the assumption in the process of test of reinforcement and concrete strain

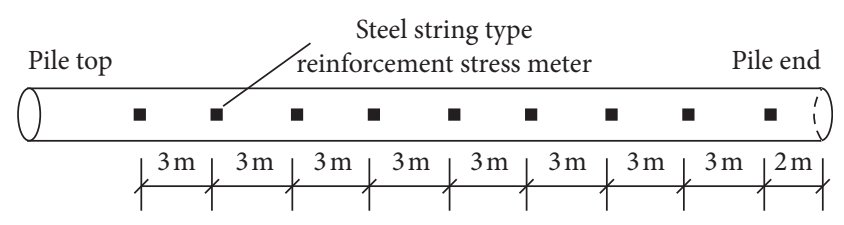

FIgURE 2: Schematic diagram of sensor distribution.

coordination, according to the calculation of reinforcing steel bar meter frequency change, characteristics of pile axial force distribution are obtained. According to the frequency value measured each time, calculate the stress value of the measuring point according to the following equation [20]:

$$
\sigma_{\mathrm{si}}=k\left(F_{0}^{2}-F_{i}^{2}\right),
$$

where $\sigma_{\mathrm{si}}$ is the $i$-th strain of the reinforcement meter $(\mathrm{kPa})$; $k$ is the constant coefficient of the reinforcement meter; $F_{0}$ is the zero frequency of the reinforcement meter $(\mathrm{Hz})$; and $F_{i}$ is the measured frequency of the reinforcement meter $(\mathrm{Hz})$.

The strain of reinforcement is expressed as

$$
\varepsilon_{i}=\frac{\sigma_{\text {si }}}{E_{s}}
$$

where $\varepsilon_{i}$ is the $i$-th strain variable of the reinforcement meter and $E_{s}$ is the elastic modulus of reinforcement $(\mathrm{MPa})$.

The concrete stress of pile body can be expressed as

$$
\sigma_{\mathrm{ci}}=E_{c} \cdot \varepsilon_{i},
$$

where $\sigma_{\mathrm{ci}}$ is the normal stress of $i$ section concrete $(\mathrm{kPa}) ; \varepsilon_{i}$ is the concrete strain of $i$ section; and $E_{c}$ is the elastic modulus of concrete (MPa).

Assuming the strain coordination between steel bar and concrete in the test process, the axial force $F_{i}$ in the $i$-th test at a section of the pile can be expressed as

$$
F_{i}=A_{\mathrm{si}} \sigma_{\mathrm{si}}+A_{\mathrm{ci}} \sigma_{\mathrm{ci}} \text {, }
$$

where $A_{\mathrm{si}}$ is the area of steel reinforcement on $i$ section $\left(\mathrm{cm}^{2}\right)$ and $A_{\mathrm{ci}}$ is the concrete area on the $i$ section $\left(\mathrm{cm}^{2}\right)$. 
The average lateral friction resistance between the two sections can be obtained by the axial force difference between the two adjacent sections, that is,

$$
q_{i}=\frac{\left(F_{i}-F_{i-1}\right)}{h_{i} U_{p}},
$$

where $q_{i}$ is the average lateral friction resistance of the $i$-th layer of soil $(\mathrm{kPa}) ; F_{i}$ and $F_{i-1}$ are the axial forces of the pile on and below the $i$-th layer of soil, respectively $(\mathrm{kN}) ; h_{i}$ is the thickness of the $i$-th layer of soil $(\mathrm{cm})$; and $U_{p}$ is the section circumference of the pile $(\mathrm{cm})$.

After testing, the survival rate of the rebar meter in this experiment is $92 \%$. During the test, the axial force $P_{z}$ of each pile under each grade of load was obtained according to equations (1) (4) based on the frequency variation of the embedded reinforcement meter in the six test piles, and the average lateral friction resistance $q_{s}$ was obtained from equation (5). The total lateral resistance $Q_{s}$ and pile end resistance $Q_{p}$ were obtained from the following equations, respectively:

$$
\begin{gathered}
Q_{s}=U_{P} \sum_{i} q_{i} h_{i}, \\
Q_{p}=Q-Q_{s},
\end{gathered}
$$

where $Q_{s}$ is the total pile side resistance $(\mathrm{kPa}) ; Q_{p}$ is pile end resistance; and $Q$ is pile top load $(\mathrm{kPa})$.

4.2. Theoretical Calculation Method of Pile Axial Force. According to the load transfer theory [21], the equation for calculating the pile axial force under the two kinds of displacement of pile top can be established as follows:

(1) Under the action of load, plastic failure occurs at the top of the pile side, with a depth of $l_{0}$ in the failure zone $\left(\Delta s(z) \geq s_{0}\right)$. The lower part is in the elastic state, its depth range is $l_{0} \sim l_{1}$, and it is in the elastic region $\left(\left(\Delta s(z) \leq s_{0}\right)\right.$. The axial force $P(z)$ in the pile body is

$$
P(z)=P_{l_{0}} \frac{\sinh \left[\eta\left(l_{0}-z\right)\right]}{\sinh \left[\eta\left(l_{1}-l_{0}\right)\right]} .
$$

(2) When the pile top is subjected to load and the surrounding rocks are in an elastic state $\left(s(z) \leq s_{0}\right)$, the axial force $P(z)$ in the pile body is

$$
P(z)=P_{d} \frac{\sinh \left[\eta\left(l_{1}-z\right)\right]}{\sinh \left(\eta l_{1}\right)} .
$$

The above equations show that the axial force distribution of rock-socketed piles can be obtained as long as the comprehensive influence coefficient $\eta$ is determined by the material properties and geometric conditions of rocksocketed piles, the surrounding rock properties and construction conditions, etc. are determined, and the Q-s curve is obtained through field rock-socketed pile tests to obtain

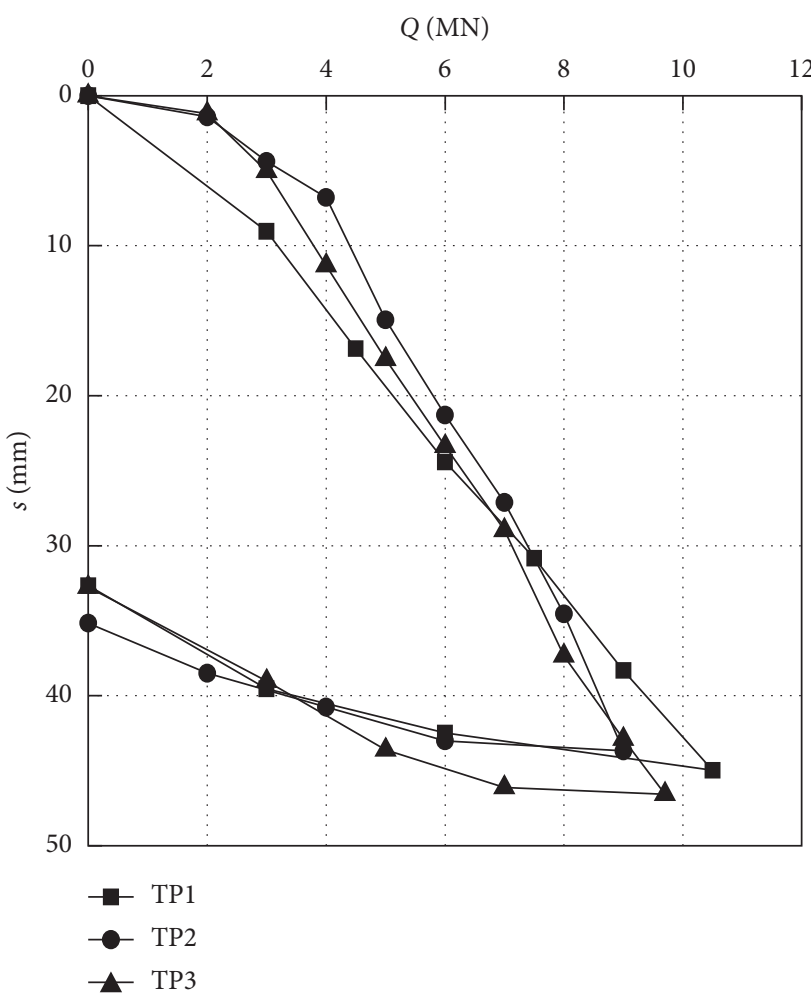

Figure 3: Q-s curves of test pile.

the force required for unit displacement of rock-socketed piles in the linear deformation section.

\section{Test Results and Analysis}

5.1. Compressive Static Load Test Results of Single Pile. $Q-s$ curves of the three test piles are shown in Figure 3. The maximum load, maximum settlement, end resistance ratio, and resilience of test pile are listed in Table 3.

As can be seen from Figure 3, Q-s curve of large-diameter rock-socketed mud wall protection bored cast-in-place pile with length-diameter ratio (L/D) of 25 33 and rocksocketed depth of $5 \mathrm{D} \sim 8 \mathrm{D}$ is of rapid growth type. Three test piles were determined as class I piles after integrity testing of low-strain pile bodies. According to the determination method of vertical ultimate bearing capacity of single pile in the code [18], when TP1, TP2, and TP3 are, respectively, loaded to $10500 \mathrm{kN}, 9000 \mathrm{kN}$, and $9700 \mathrm{kN}$, the anchor pile appears obviously uplifted, and the maximum settlement exceeds $40 \mathrm{~mm}$, and the vertical ultimate bearing capacity of single pile can be judged to be $9378 \mathrm{kN}, 8597 \mathrm{kN}$, and $9000 \mathrm{kN}$, respectively. At the initial stage of loading, the settlement of TP1 increased greatly and is rapidly compared with other test piles. This is mainly because the soil layer in the non-rock-socketed section of test pile TP1 has less lateral constraint, and the relative displacement of pile and soil is larger, and the Q-s curve at the initial stage is nearly linear. When the load exceeds $6000 \mathrm{kN}$, the Q-s curve grows slowly. At this point, the lateral friction resistance of soil layer piles gradually develops, the relative displacement of pile soil 
TABLE 3: Deformation and capacity of test piles.

\begin{tabular}{|c|c|c|c|c|c|c|c|c|c|}
\hline $\begin{array}{l}\text { Test pile } \\
\text { number }\end{array}$ & $L / D$ & $\begin{array}{c}\text { Rock- } \\
\text { socketed } \\
\text { depth }(m)\end{array}$ & $\begin{array}{l}\text { Maximum } \\
\text { load }(\mathrm{kN})\end{array}$ & $\begin{array}{l}\text { Standard value } \\
\text { of ultimate } \\
\text { bearing capacity } \\
(\mathrm{kN})\end{array}$ & $\begin{array}{l}\text { Pile end } \\
\text { resistance } \\
\left(\times 10^{2} \mathrm{kN}\right)\end{array}$ & $\begin{array}{l}\text { End } \\
\text { resistance } \\
\text { ration }\end{array}$ & $\begin{array}{l}\text { Maximum } \\
\text { settlement } \\
(\mathrm{mm})\end{array}$ & $\begin{array}{l}\text { Residual } \\
\text { sedimentation } \\
\text { rate }(\%)\end{array}$ & $\begin{array}{l}\text { Resilient } \\
\text { rate }(\%)\end{array}$ \\
\hline TP1 & 25.55 & 5.49 & 10500 & 9378 & 69 & 2 & 44.98 & 72.6 & 27.4 \\
\hline TP2 & 31.88 & 5.52 & 9000 & 8597 & 29 & $1 / 2$ & 43.68 & 80.5 & 19.5 \\
\hline TP3 & 33.13 & 6.42 & 9700 & 9000 & 36 & $2 / 3$ & 46.56 & 70.4 & 29.6 \\
\hline
\end{tabular}

decreases, and the settlement of pile top mainly depends on the settlement of pile end.

In the same geotechnical layer, the Q-s curves of TP2 (treated by post-pile grouting) are consistent with those of TP1 and TP3 (the length-diameter ratio and rock-socketed depth are both small). The reason is that, at $16 \mathrm{~m}$ of pile TP2, under the influence of the grouting construction quality behind the pile (the grouting pressure and water cement of the pile are relatively high), the ultimate friction resistance of the pile side in rock-socketed section is weakened, and the load is mainly borne by the lateral friction resistance provided by the overlying soil layer of weathered rock, and the load sharing ratio between pile end and pile side is about 1: 4 . TP1 with a diameter of $1.0 \mathrm{~m}$ shows the characteristics of friction end bearing pile. The ultimate friction resistance on the pile side of the rock and soil layer below the fourth layer of silty clay is limited by the construction quality of the castin-place pile. The load sharing ratio between the pile end and the pile side is about $1: 1$ to $1: 2$. When TP1 was loaded at grade 1 and TP3 was loaded at grade 2, the load and settlement showed a near-linear change, indicating that the pile top load was mainly borne by the pile end and the bearing capacity of the pile side and the pile end was quite different. After applying the 1st grade load, TP2 shows a broken line change with the increase of the load, and the slope gradually increases. When the load reaches $9000 \mathrm{kN}$, the settlement of the pile top exceeds the allowable value of the specification (40 $\mathrm{mm})$.

As can be seen from Table 3, the length-diameter ratio, rock-socketed depth, construction technology, and pile quality of large-diameter bored piles have great influence on the deformation characteristics of piles. Under the same rock-soil layer condition, when the $\mathrm{L} / \mathrm{D}$ is $25-33$ and the rock-socketed depth is within the range of $5 \mathrm{~d}-8 \mathrm{~d}$, compared with TP1 and TP3 without the postgrouting treatment, the ultimate compressive bearing capacity of single pile does not increase, the maximum settlement is reduced by $6.6 \%$, and the rebound rate is also significantly reduced, about $11.1 \%$. The ability to control the settlement of pile top is not significantly improved. Under the test conditions, compared with TP1, when the L/D and rock-socketed depth of TP3 without lateral grouting were increased by $29.7 \%$ and $16.9 \%$, respectively, the bearing capacity was reduced by $4.0 \%$, the maximum settlement increased by $3.5 \%$, and the rebound rate was increased by $8.0 \%$. In conclusion, the settlement amount of TP1 mainly comes from the settlement of pile end. Compared with TP3, the strength of mud skin on the pile side is greater. The lateral friction resistance of the pile in the soil layer above the rock-socketed section plays an earlier role, so the bearing capacity decreases and the resilience of the pile body decreases. The settlement of TP3 pile top is mainly due to the compression of pile end. The pile end bears the load of pile top early, and the resistance of pile end is large. The relative displacement of pile soil at the pile end increases, and the lateral friction resistance of pile is small. To sum up, it shows that the bearing capacity of the piles without lateral backgrouting is greatly affected by the length-diameter ratio, while the deformation characteristics are greatly affected by the rock-socketed depth.

5.2. Variation Rule of Pile Axial Force. As can be seen from Figure 4, the axial forces of three large-diameter rocksocketed cast-in-place piles are consistent with the distribution law of the pile bodies and gradually decline from top to bottom. The attenuation curves are of the inner concave and outer convex types. The variation rule is related to the length-diameter ratio of piles, the soil layer properties around piles and pile ends, the depth of rock-socketed, the way of piling, the quality and the construction technology, etc. Through the adjacent soil pile axial force statistics found that the average relative attenuation of similar length to diameter ratio and rock-socketed depth and pile quality is stable, the pile grouting treatment is compared with pile without grouting treatment of piles, pile axial force of average relative attenuation rate increase is larger, and the coarse sand (loose) layer can be increased by $66.7 \%$. The layer of medium coarse sand (slightly dense to medium dense) can increase $33.3 \%$. The silty clay layer (plasticized, $\left.I_{L}=0.47\right)$ decreased by $1.62 \%$, a relatively small decrease. The medium coarse sand (medium dense) layer decreased by $5.88 \%$, which was relatively small. The residual viscous soil layer (hard plastic, $I_{L}=0.4$ ) was reduced by $20.8 \%$, a relatively large decrease. Postgrouting has a stronger strengthening effect on the soil layer above the socketed rock. When the pile quality is poor (the axial force of TP1 and TP 3 piles in Figure 3 decreases slowly along the depth, it can be inferred that there is a thick mud skin on the pile side, and the strength is low), the relative attenuation rate of the axial force of pile is reduced by $20.5 \% \sim 34 \%$ in the shallow soil layer about $6 \mathrm{D} \sim 8 \mathrm{D}$ from the pile top. In the dense soil layer in the middle and lower part from the pile top for $10 \mathrm{D} \sim 20 \mathrm{D}$, the decrease was $18.5 \% \sim 60 \%$, with an average decrease of $39.3 \%$. In fully weathered strata, the decrease was $51.1 \%$, and in strongly weathered strata, $70.7 \%$.

Taking TP3 as an example, the theoretical calculated value and the measured value of its axial force are compared and analyzed [22, 23]. According to $Q-s$ curve, the 


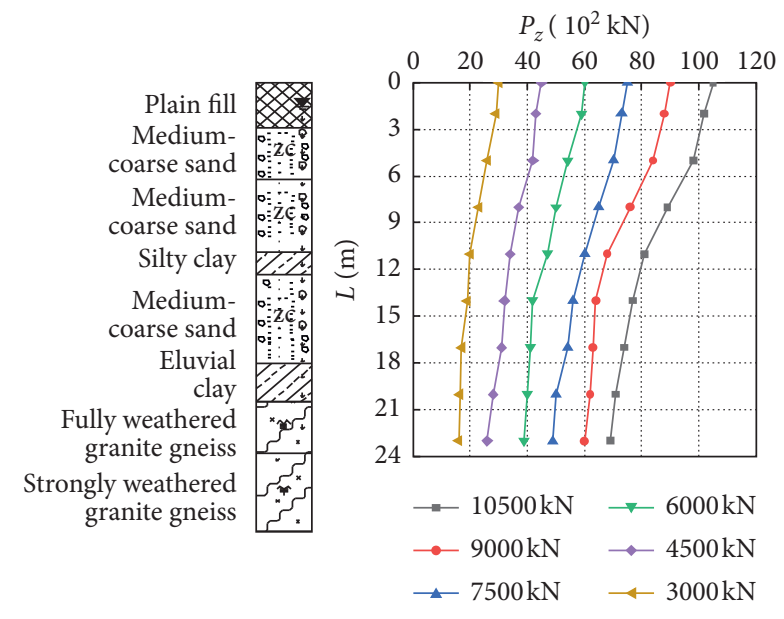

(a)

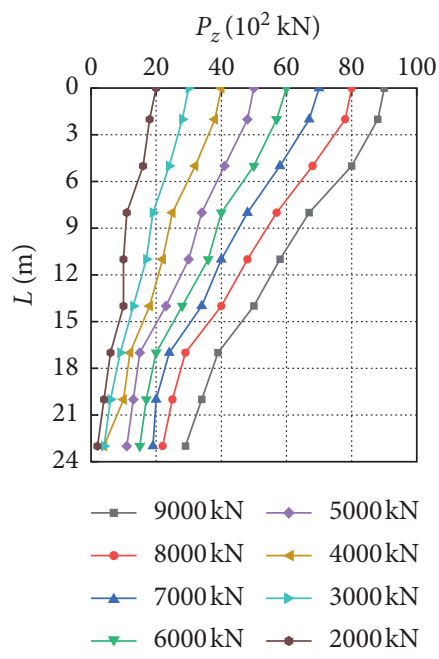

(b)

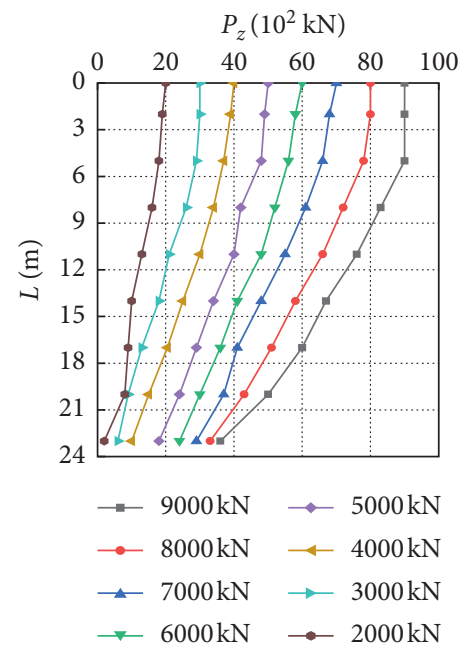

(c)

FIgURE 4: The distribution curve of axial force along pile. (a) TP1. (b) TP2. (c) TP3.

displacement of pile top corresponding to $8000 \mathrm{kN}$ and $9000 \mathrm{kN}$ is $1.2 \mathrm{~mm}$ and $2.4 \mathrm{~mm}$, respectively. Through analysis and calculation, the pile rock displacement limit value $s_{0}=1.7 \mathrm{~mm}, \eta=0.11$. Therefore, the load of $8000 \mathrm{kN}$ and $9000 \mathrm{kN}$ corresponds to the load under elastic state and plastic failure, respectively. According to the above calculation equation, the axial force under elastic and plastic failure can be obtained along the rock-socketed depth transfer curve, as shown in Figures 5 and 6, respectively.

In Figure 5, the pile top load is $80 \mathrm{MN}$, and the pile top displacement is $37 \mathrm{~mm}$, which is less than the elastic limit displacement value and is in the elastic shear state. The theoretical curve is a smooth hyperbola, which is consistent with the measured line. In Figure 6, the pile top load is $90 \mathrm{MN}$, and the theoretical value under the pile top displacement is $42 \mathrm{~mm}$, compared with the measured value. Since the pile top displacement is larger than the elastic limit displacement value, it is calculated in sections, the depth of the failure zone is $4.08 \mathrm{~m}$, and the failure load is $52 \mathrm{MN}$, which is basically at the same depth as the linear folding point $(4 \mathrm{~m})$ of the measured load transfer curve.

\subsection{Variation Rule of Average Lateral Friction Resistance on} Pile Side. As can be seen from Figure 7, the vertical variation of pile lateral friction at the junction of soft and hard soil layers is manifested by sudden change of pile lateral friction. The lateral change rule is that, with the increase of pile top load, the lateral friction of pile first increases linearly, then gradually shows a nonlinear increase, and then gradually decreases and tends to be stable after reaching the limit of lateral friction. For the bored piles with mud wall protection (the rock-socketed depth is $5 \mathrm{D} \sim 8 \mathrm{D}$ ), the lateral friction resistance of the grouting and nongrouting piles in the fully weathered and highly weathered rocks is played in the upper small lower large mode.

By comparing test piles TP1 $\sim$ TP3, it can be found that the pile lateral friction resistance can be increased by $31.25 \%$

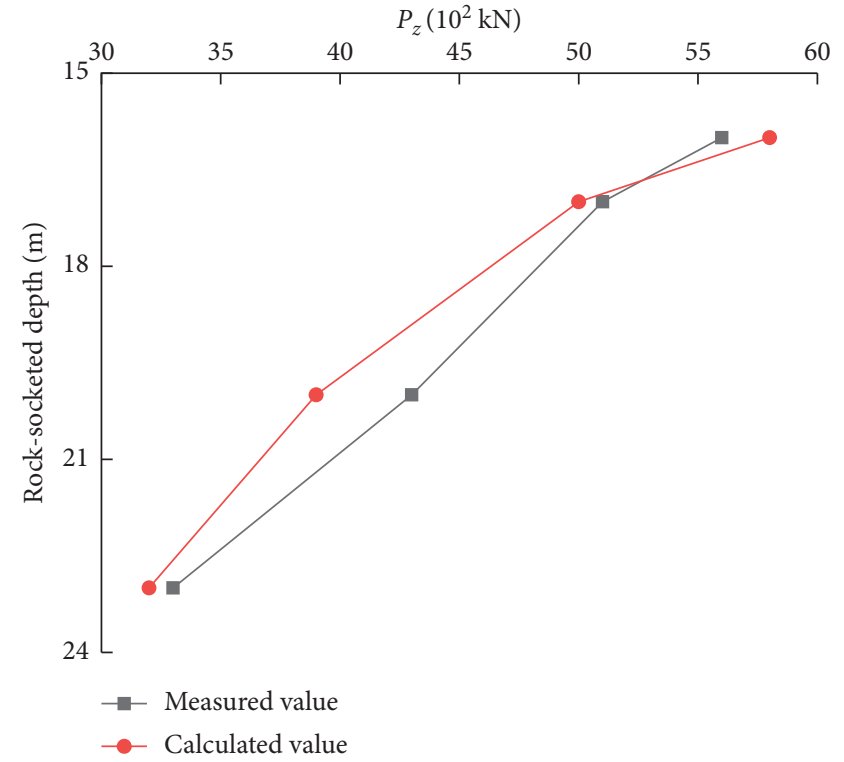

FIGURE 5: Distribution of pile axial force when wall rock is elastic.

in the plain filled soil layer compared with the test piles without the lateral grouting treatment. Medium coarse sand (loose) layer can be increased by $0.7 \%$, and medium coarse sand (slightly dense to medium dense) layer can be increased by $19.1 \%$. Silty clay layers (malleable, $I_{L}=0.47$ ) increased by $19.0 \%$. Medium coarse sand (medium dense) layer decreased by $1.7 \%$; residual viscous soil (hard plastic, $I_{L}=0.4$ ) increased by $10.0 \%$; the lateral friction resistance of rocksocketed pile plays a small role, which indicates that postgrouting plays a relatively large role in strengthening the lateral friction resistance of the pile above the fully weathered and strongly weathered gneiss beds. When the lengthdiameter ratio is consistent with the rock-socketed depth of the test pile without lateral grouting treatment, the pile with good construction quality (class I pile, without thicker mud 


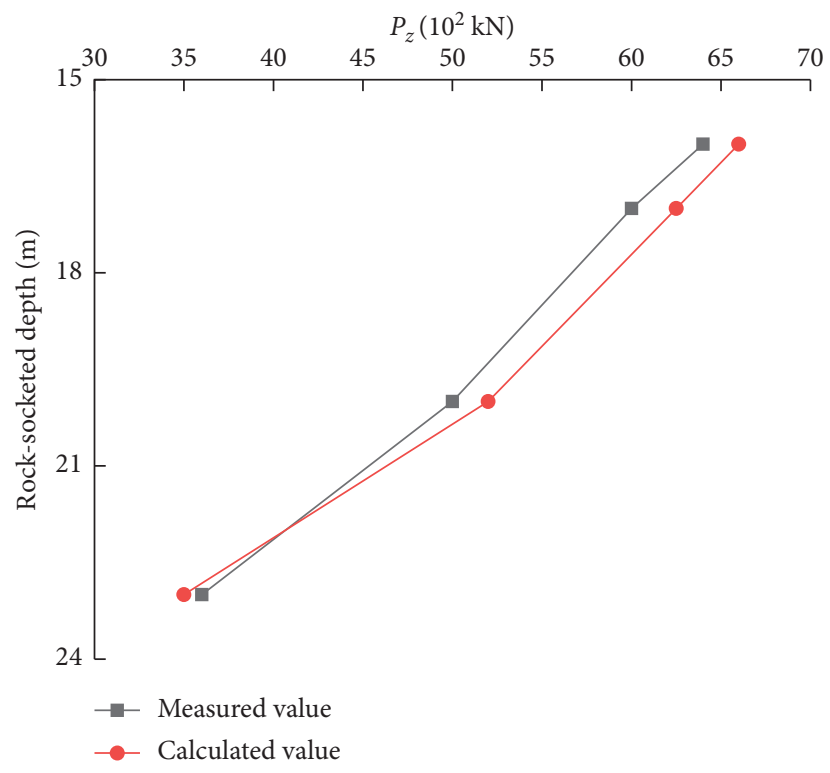

FIgURE 6: Distribution of pile axial force when partial wall rock is plastic.

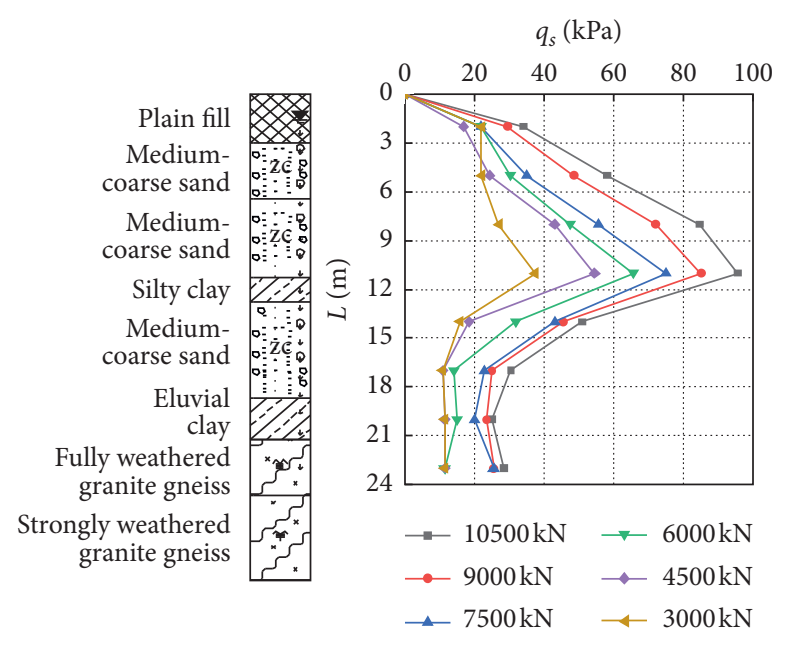

(a)

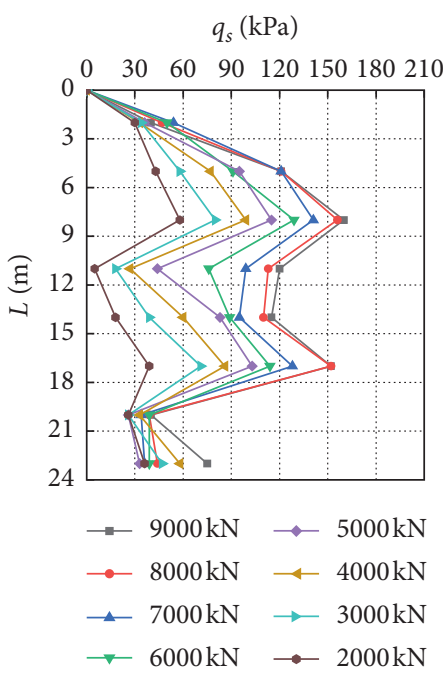

(b)

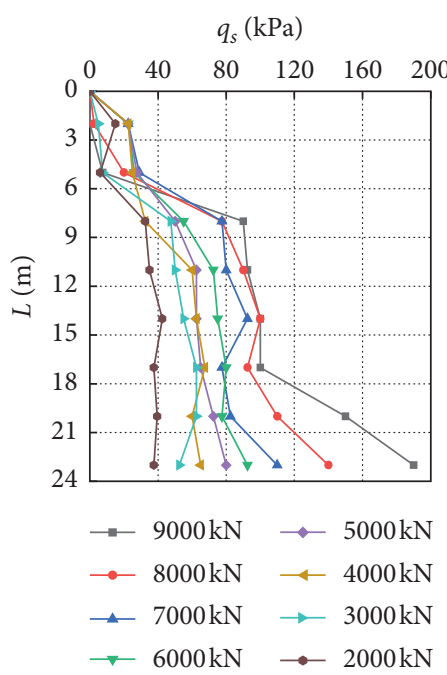

(c)

Figure 7: The distribution of pile side friction along pile. (a) TP1. (b) TP2. (c) TP3.

skin) can increase the lateral friction resistance of the pile in the plain filled soil layer by $17.6 \%$. The medium coarse sand (loose) layer can be increased by $24.1 \%$. The layer of medium coarse sand (slightly dense $\sim$ medium dense) can be increased by $1.4 \%$. The silty clay layer (malleable, $I_{L}=0.47$ ) increased by $4.7 \%$. Medium coarse sand (medium dense) layer can be increased by $17.0 \%$. Residual viscous soil (hard plastic, $\left.I_{L}=0.4\right)$ increased by $19.0 \%$. The fully weathered rock section can first increase by $51.0 \%$ and then decrease by $48 \%$. The highly weathered rock segment can be increased by $141 \%$. When the length-diameter ratio is consistent with the rock-socketed depth, the good grouting effect (the grouting pressure and water-cement ratio reach the grouting standard and are not too large) can increase the lateral friction resistance of piles in the plain soil layer by $59.1 \%$. The medium coarse sand (loose) layer can be increased by $48.8 \%$. The layer of medium coarse sand (slightly dense $\sim$ medium dense) can be increased by $42.9 \%$. The silty clay layer (plasticized, $I_{L}=0.47$ ) increased by $42.5 \%$ at first and then decreased by $29.8 \% \%$, a relatively small decrease. Medium coarse sand (medium dense) layer can be increased by $26.1 \%$. The residual viscous soil layer (hard plastic, $I_{L}=0.4$ ) increased by $20.9 \%$ and then decreased by $27.6 \%$, with a relatively small decrease. The fully weathered rock layer can be increased by $7.14 \%$ and decreased by $28.6 \%$. Strongly weathered rock formations can be raised by $7.14 \%$ to $78.6 \%$. It can be seen that the strengthening effect of postgrouting on pile lateral friction is weak in rock-socketed section. This 
is because the grouting pressure and water-cement ratio of rock-socketed section are too large under test conditions, resulting in segregation of cement slurry to a certain extent, thus weakening the shear strength of the interface and limiting the lateral friction resistance of the pile in rocksocketed section. Therefore, under the condition that the length-diameter ratio and rock-socketed depth are the same, compared with TP2, the lateral friction resistance of pile in rock-socketed segment plays a greater role.

5.4. Deformation Characteristics of Rock-Socketed Pile. According to the settlement data obtained in the failure test, the variation rules of the settlement with the lateral friction resistance and pile end resistance were drawn, as shown in Figure 8.

As can be seen from Figure 8, TP1 shows the behavior of pile bearing at the frictional end. With the increase of settlement at the pile top, the pile end resistance increases linearly, and the load on the pile top is mainly borne by the pile end. The ultimate frictional resistance of pile side is firstly developed in the middle and upper soil layers of pile body, and the ultimate frictional resistance of pile side of residual viscous soil, medium coarse sand layer, and rock-socketed section is relatively small within the range of $12 \mathrm{D} \sim 20 \mathrm{D}$ from pile top. Therefore, when the settlement of pile top exceeds $25 \mathrm{~mm}$, the total pile lateral friction gradually increases, but the increase range is small, and the settlement of pile top mainly comes from the settlement of pile end. TP2 shows the behavior of end-bearing friction pile. Compared with the test pile without lateral grouting treatment, the lateral friction resistance of pile is more fully developed. TP2 and TP3 have the same change rules, and the curve changes slowly. The vertical distance between pile lateral friction resistance and pile end resistance change curves is small and uniform, and the load sharing capacity of pile lateral friction resistance is limited. Pile end resistance plays an early role, with a low bearing capacity and a large settlement.

The load-bearing ratio between the pile side and the equivalent pile end of each test pile and the ratio between the ultimate frictional resistance of the pile side in rock-socketed section to the total ultimate lateral frictional resistance, the length-diameter ratio, and the rock-socketed depth are shown in Figures 9 and 10.

As can be seen from Figures 9 and 10, under this test condition, the increase of $\left(q_{\mathrm{gs}} / q_{s}\right)$ of the test pile without postgrouting treatment on the side of the pile reaches $218.0 \%$ with the increase of length-diameter ratio, indicating that the rock-socketed section of the test pile TP 3 has a certain strength of soil skin on the side of the pile, and its rocksocketed section has a greater normal constraint, so the pile quality is better, and it is greatly affected by the lengthdiameter ratio and rock-socketed depth. It can be found from the comparison of various test piles that, compared with TP2 treated with lateral postgrouting and TP1 treated with nonlateral postgrouting, the pile end resistance sharing ratio $\left(Q_{p} / Q\right)$ has little change, which indicates that the grouting treatment does not significantly improve the pile quality. Compared with TP1, the length-diameter ratio

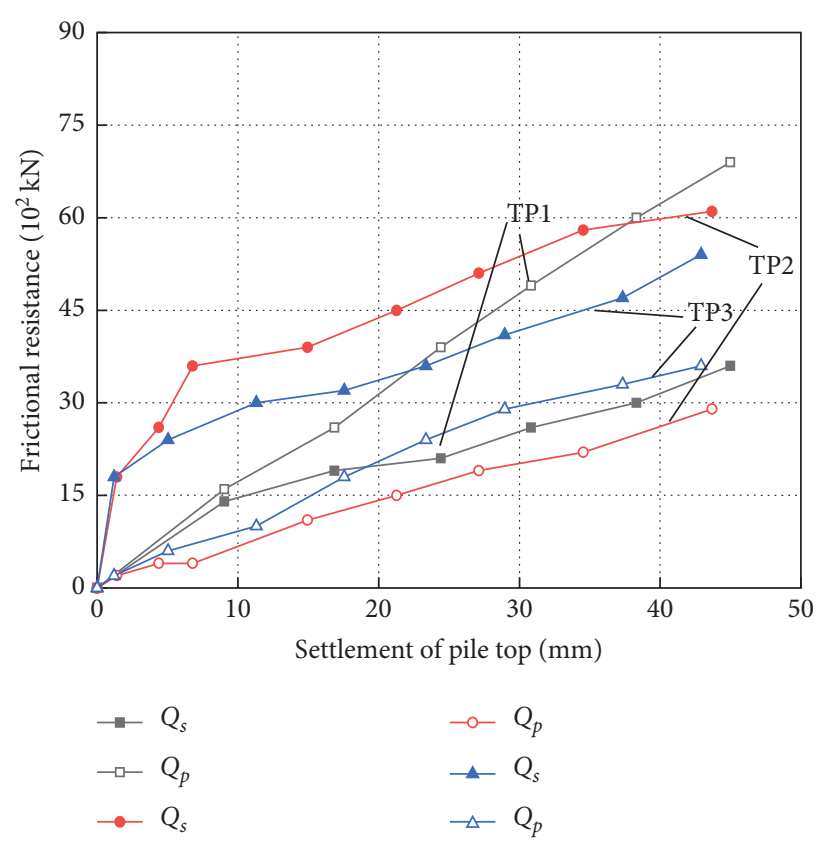

FIGURE 8: The curves of friction resistance and pipe top settlement.

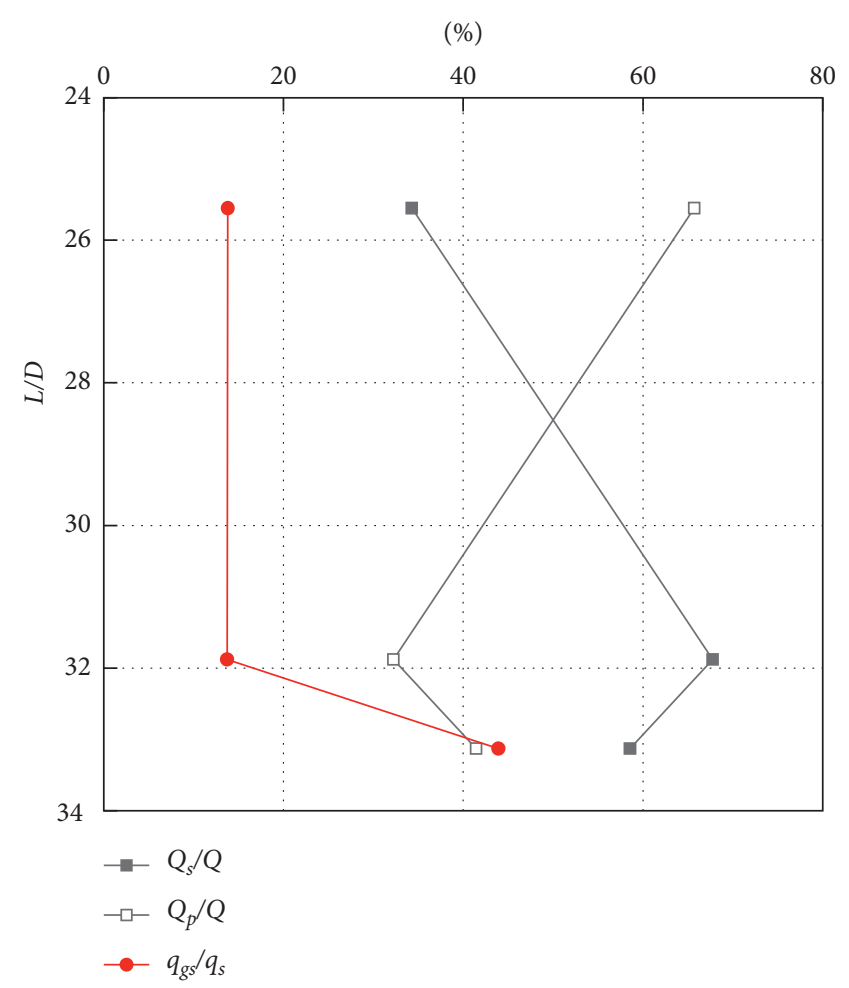

Figure 9: The curves of load sharing ratio and aspect ratio.

increased by $29.7 \%$ and the rock-socketed depth increased by $16.9 \%$, but the $\left(Q_{p} / Q\right)$ decreased by $37.0 \%$. Compared with TP1, the length-diameter ratio and rock-socketed depth of test pile TP3 without lateral grouting increased by $29.7 \%$ and $16.9 \%$, respectively, but the $\left(Q_{p} / Q\right)$ decreased by $37.0 \%$. It shows that $\left(Q_{p} / Q\right)$ is always significantly affected by rocksocketed depth, whether or not it is treated by post-pile 


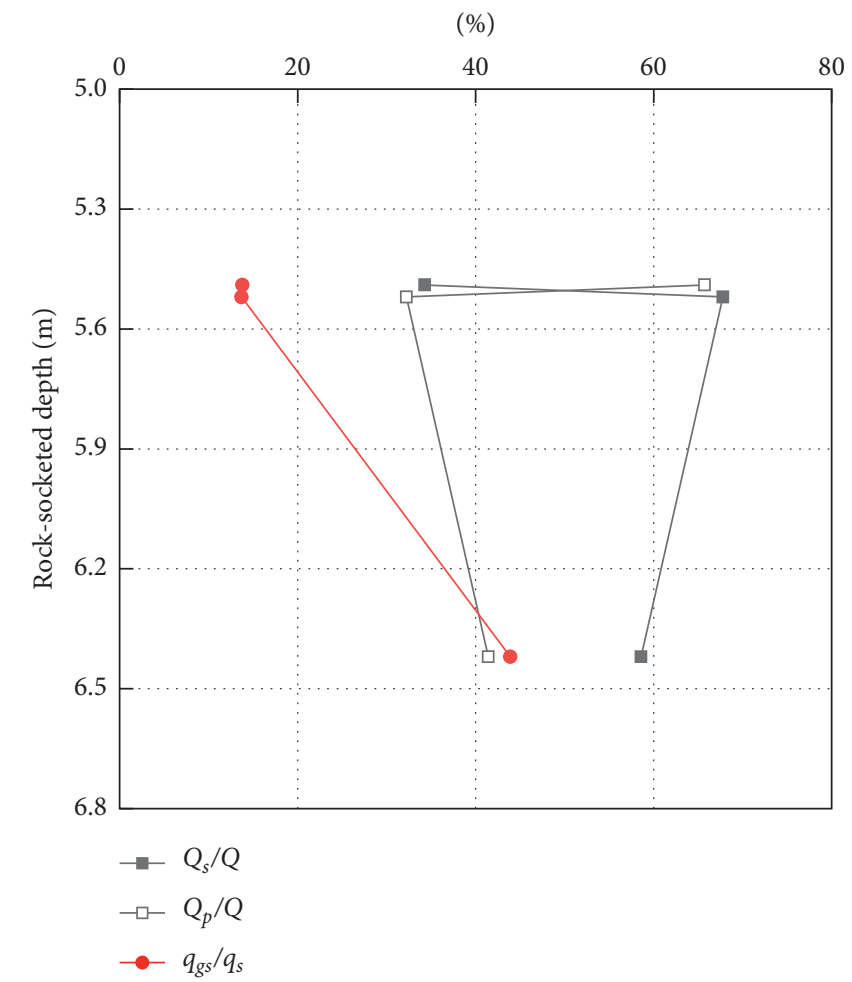

FIgURE 10: The curves of load sharing ratio and rocking depth.

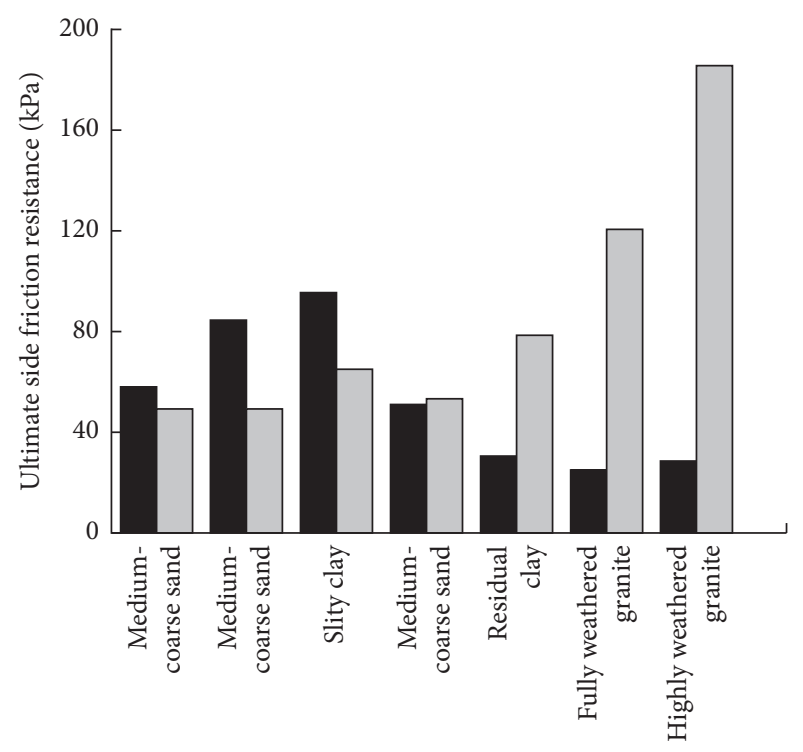

Measured values

$\square$ Recommended value of survey report

(a)

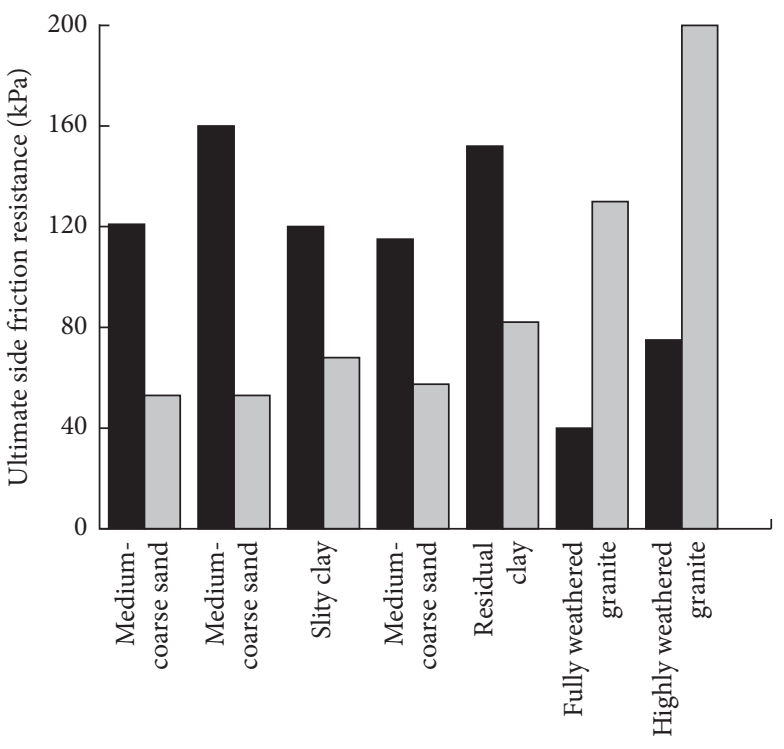

Measured values

$\square$ Recommended value of survey report

(b)

Figure 11: Continued. 


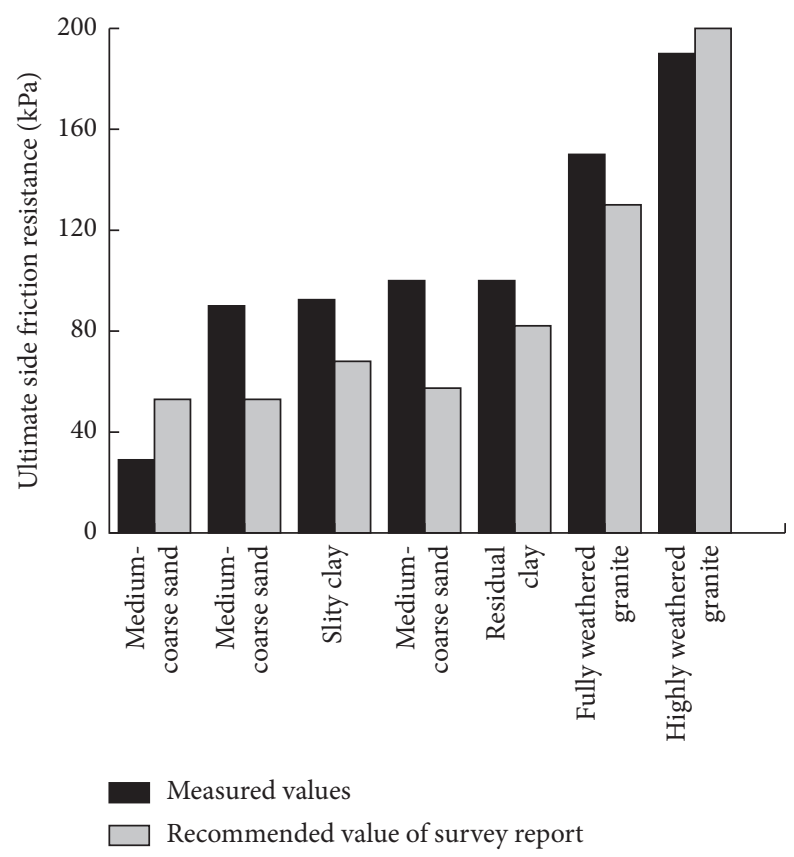

(c)

FIgURe 11: Pile shaft skin ultimate friction and code value in different soil layers. (a) TP1. (b) TP2. (c) TP3.

grouting. Under this test condition, for the test pile without grouting treatment, the pile side friction resistance sharing ratio $\left(Q_{s} / Q\right)$ increased by $70.8 \%$ with the increase of lengthdiameter ratio and rock-socketed depth. $\left(Q_{s} / Q\right)$ was greatly affected by rock-socketed depth. $\left(Q_{s} / Q\right)$ was not affected by length-diameter ratio and rock-socketed depth in the test pile after grouting.

5.5. Comparative Analysis. The measured value of ultimate friction resistance on the pile side was compared with the recommended value of the survey report, and the enhancement coefficient of lateral friction resistance on the postgrouting pile and the size effect coefficient on the large-diameter pile side were compared with the recommended value of technical specification for building pile foundation (JGJ94-2008) [18], as shown in Figures 11-13.

Figure 11 shows that, in the guarantee slurry-supported drilled filling pile under the premise of the quality of pile (duration of thickness of mud, mud, mud consistency), the combination of Figure 6 and the characteristics of the frictional end bearing pile can be judged. TP1 part shows thick mud by the pile side; the test pile side friction resistance limits some of its soil compared with the standard value, which is larger. Medium coarse sand (loose) can be increased by $17.9 \% \sim 46.4 \%$, medium coarse sand (slightly dense $\sim$ medium dense) by $71.8 \% \sim$ $91.1 \%$, silty clay (plasticized, $I_{L}=0.47$ ) by $46.9 \% \sim 53.8 \%$, medium coarse sand (medium dense) by $74.2 \% \sim 120 \%$, and residual viscous soil (hard plastic, $I_{L}=0.4$ ) by $7.02 \% \sim 21.8 \%$. TP3's ultimate frictional resistance in fully weathered rock formations increased by only $15.4 \%$ compared to the recommended values in the survey report. The reason is that, in combination with Figure 6, the ultimate friction resistance on the pile side of TP1 is limited, and the strength of rock-socketed section is lower than the general soil layer. It can be seen from Figure 7 that the pile end resistance plays a big role, and the pile side friction resistance in the strongly weathered rock stratum has begun to play its role. However, the fully weathered rock stratum does not increase significantly when playing its role in the upper layer but has limited potential and is greatly affected by the construction quality. Regarding TP2 under the influence of grouting quality, the pile side friction resistance in rocksocketed section is weakened due to the high grouting pressure. As can be seen from Figure 12, for the cast-inplace pile $(D=1.0 \mathrm{~m})$, the size effect coefficient of pile side in sand can be increased by $17.9 \% \sim 120 \%$, with a large increase. It can be increased by $7.01 \% \sim 53.9 \%$ in viscous soil. For the cast-in-place pile with a pile diameter of $0.8 \mathrm{~m}$, the size effect coefficient of pile side can be increased by $69.8 \% \sim 74.2 \%$ in sandy soil and $72.0 \%$ on average, which is mainly and significantly increased by $21.8 \% \sim 36.0 \%$ in viscous soil. The measured value is much higher than the standard value. As can be seen from Figure 12, by comparing the measured pile side friction resistance value with the standard value of initial limit pile side friction resistance determined by the specification [18], it is found that the enhanced coefficient of pile side friction resistance after grouting can be increased by $8.43 \%$ in the medium coarse sand layer and $2.8 \%$ in the viscous soil, and the measured value is slightly higher than the recommended value of the specification. 


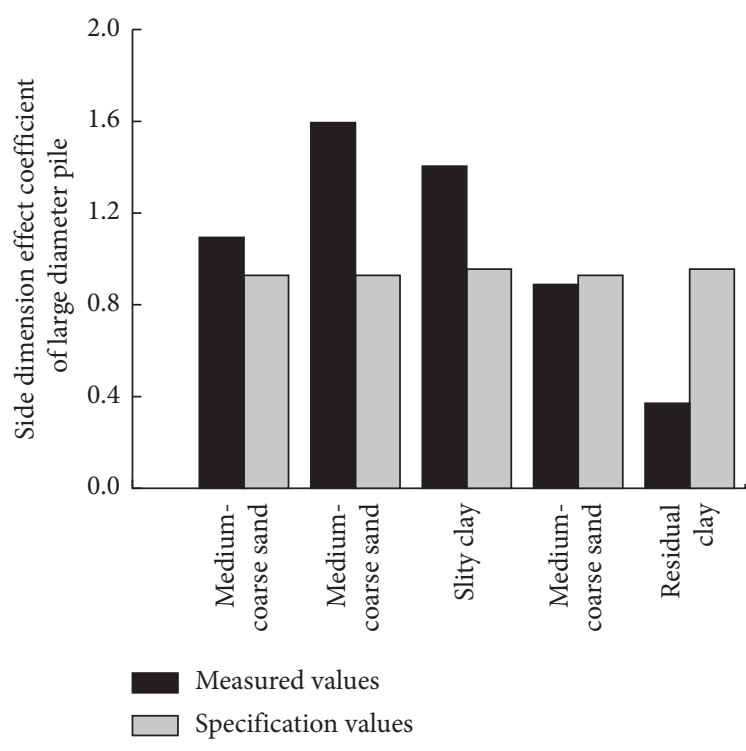

(a)

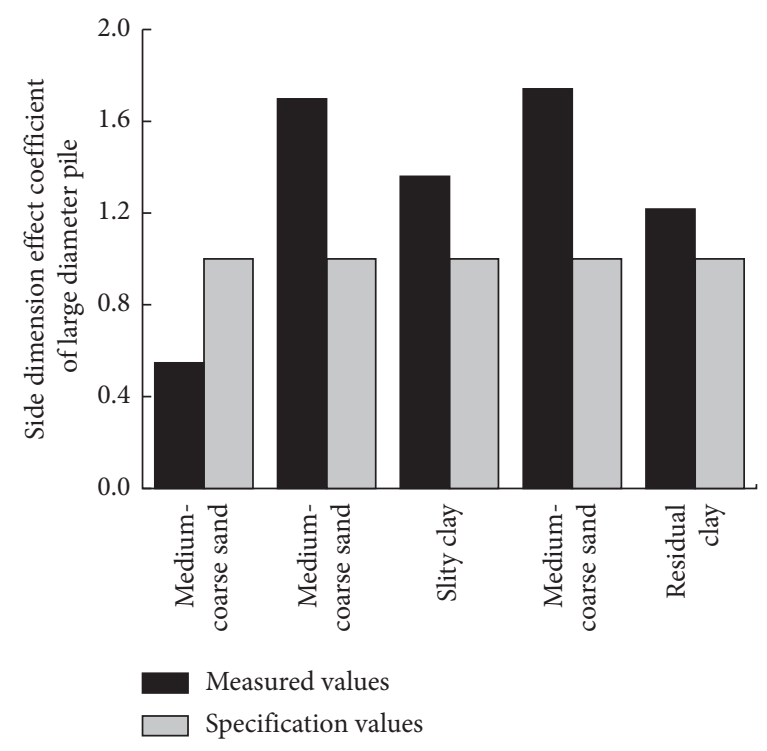

(b)

Figure 12: Size effect coefficient of pile side and code value in different soil layers. (a) TP1. (b) TP3.

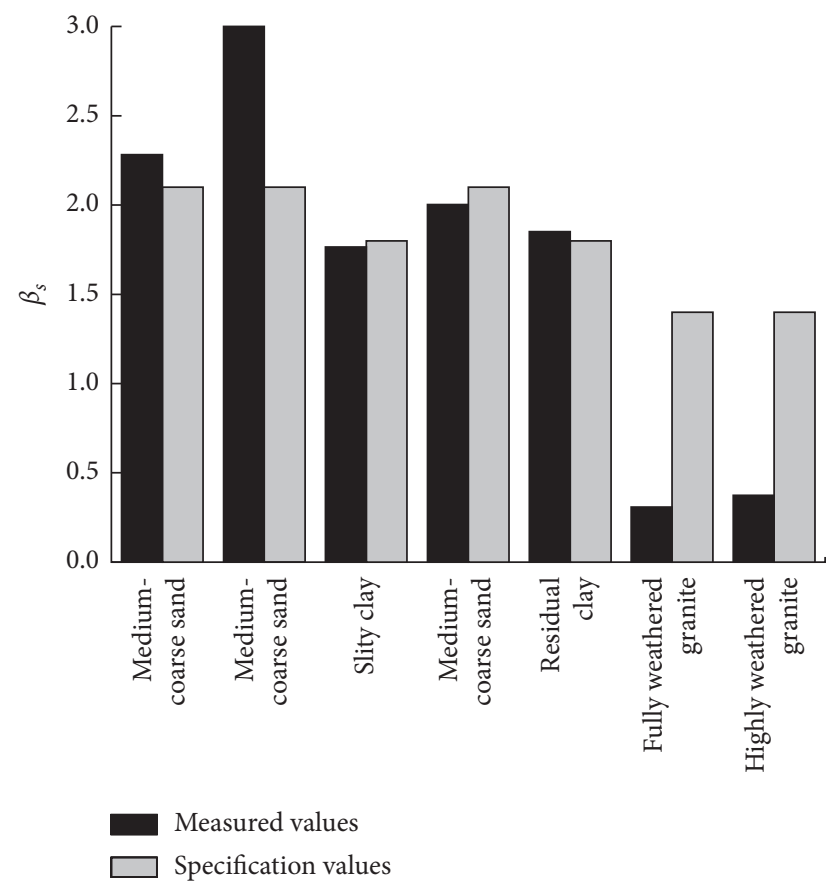

FIGURE 13: Side friction resistance enhancement factor of the postgrouting pile and code value in different soil layers.

\section{Conclusions}

(1) Under the test conditions, the axial force attenuation curve of the pile body of the large diameter mud retaining wall bored cast-in-situ pile was of a steep drop. The ultimate bearing capacity of the cast-inplace piles treated with postpile grouting is not significantly improved compared with the cast-inplace piles without postpile grouting.
(2) The ultimate bearing capacity of single pile was increased by $1.40 \%$, the maximum settlement was decreased by $6.2 \%$, the rebound rate was not improved significantly, and the effect of controlling the settlement of pile top was enhanced. Under the test conditions, the bearing capacity and deformation characteristics of the three test piles are greatly affected by length-diameter ratio and rock-socketed depth. 
(3) After the grouting treatment, the lateral frictionresistance ratio of rock-socketed section $\left(q_{\mathrm{gs}} / q_{s}\right)$ was reduced under the influence of length-diameter ratio and rock-socketed depth. The pile end resistance ratio $\left(Q_{p} / Q\right)$ is significantly affected by the rock-socketed depth. After postgrouting treatment, the lateral friction-resistance ratio $\left(Q_{s} / Q\right)$ is almost negligible under the influence of length-diameter ratio and rock-socketed depth, while $\left(Q_{s} / Q\right)$ is more significantly under the influence of rock-socketed depth for test piles without postgrouting treatment.

(4) The measured value of pile side ultimate friction resistance in some soil layers is higher than the recommended value in the survey report. The increase was $71.8 \%$ in medium coarse sand (slightly dense to medium dense), $46.9 \%$ in silty clay (plasticized, $I_{L}=0.47$ ), and $74.2 \%$ in medium coarse sand (medium dense).

(5) For the cast-in-place pile with a pile diameter of $1.0 \mathrm{~m}$, the pile side size effect coefficient was larger in sandy soil and only increased by $7.01 \%$ in viscous soil. For the cast-in-place pile with a pile diameter of $0.8 \mathrm{~m}$, the pile side size effect coefficient is also larger in sandy soil, which can be increased by $21.8 \%$ in viscous soil. The lateral friction coefficient can be increased by $8.43 \%$ in the sand and $2.8 \%$ in the viscous soil.

\section{Data Availability}

The experimental data used to support the findings of this study will be made available upon request.

\section{Conflicts of Interest}

The authors declare that there are no conflicts of interest regarding the publication of this paper.

\section{Acknowledgments}

The authors would like to acknowledge the support by the National Natural Science Foundation of China (grant nos. 51708316, 51778312, and 51809146), the China Postdoctoral Science Foundation Funding (grant no. 2018M632641), the Shandong Key Research and Development Program (grant nos. 2017GSF16107 and 2018GSF117008), the Shandong Provincial Postdoctoral Innovation Program of China (grant no. 201903043), Project of Shandong Province Higher Educational Science and Technology Program (grant no. J16LG02), and Qingdao Postdoctoral Applied Research Program (grant no. 2018101).

\section{References}

[1] M. H. Nguyen and B. H. Fellenius, "Bidirectional cell tests on non-grouted and grouted large-diameter bored piles," Journal of Geo-Engineering Sciences, vol. 2, no. 3-4, pp. 105-117, 2015.

[2] Q. Zhang, Z. Zhang, F. Yu, and J. Liu, "Field performance of long bored piles within piled rafts," Proceedings of the
Institution of Civil Engineers-Geotechnical Engineering, vol. 163, no. 6, pp. 293-305, 2010.

[3] R. Radhakrishnan and C. F. Leung, "Load transfer behavior of rock-socketed piles," Journal of Geotechnical Engineering, vol. 115, no. 6, pp. 755-768, 1989.

[4] N.-W. Liu, Z.-M. Zhang, Q.-Q. Zhang, and K. Fang, "Destructive field tests on mobilization of end resistance of castin-situ bored piles," Journal of Central South University, vol. 20, no. 4, pp. 1071-1078, 2013.

[5] C. Haberfield and B. Collingwood, "Rock-socketed pile design and construction: a better way?" Proceedings of the Institution of Civil Engineers. Geotechnical Engineering, vol. 159, no. 3, pp. 207-217, 2006.

[6] L. Zhang, "Prediction of end-bearing capacity of rock-socketed shafts considering rock quality designation (RQD)," Canadian Geotechnical Journal, vol. 47, no. 10, pp. 1071-1084, 2010.

[7] S.-C. Li, Q. Zhang, Q.-Q. Zhang, and L.-P. Li, "Field and theoretical study of the response of super-long bored pile subjected to compressive load," Marine Georesources \& Geotechnology, vol. 34, no. 1, pp. 71-78, 2016.

[8] J. R. Omer, J. R. Omer, R. B. Robinson, R. Delpak, and J. K. C. Shih, "Large-scale pile tests in Mercia mudstone: data analysis and evaluation of current design methods," Geotechnical and Geological Engineering, vol. 21, no. 3, pp. 167200, 2003.

[9] S. Thiyyakkandi, M. Mcvay, D. Bloomquist, and P. Lai, "Experimental study, numerical modeling of and axial prediction approach to base grouted drilled shafts in cohesionless soils," Acta Geotechnica, vol. 9, no. 3, pp. 439-454, 2014.

[10] H. Xing, J. Han, and C. Li, "Performance monitoring of superlarge-diameter rock-socketed piles by optic fiber sensors," Materials Testing, vol. 59, no. 6, pp. 585-590, 2017.

[11] E. G. Balakrishnan, A. S. Balasubramaniam, and N. PhienWej, "Load deformation analysis of bored piles in residual weathered formation," Journal of Geotechnical and Geoenvironmental Engineering, vol. 125, no. 2, pp. 122-131, 1999.

[12] J.-J. Zhou, X.-N. Gong, K.-H. Wang, R.-H. Zhang, and J.-J. Yan, "Testing and modeling the behavior of pre-bored grouting planted piles under compression and tension," Acta Geotechnica, vol. 12, no. 5, pp. 1061-1075, 2017.

[13] W. Xu, B. Liu, Y.-Q. Zhou, and Y.-H. Han, "Construction of $8.0 \mathrm{~m}$ diameter rock-socketed piles in a large-scale deep excavation," Geotechnical and Geological Engineering, vol. 35, no. 5, pp. 2455-2466, 2017.

[14] C. Zhan and J.-H. Yin, "Field static load tests on drilled shaft founded on or socketed into rock," Canadian Geotechnical Journal, vol. 37, no. 6, pp. 1283-1294, 2000.

[15] H. Seol, S. Jeong, and S. Cho, "Analytical method for loadtransfer characteristics of rock-socketed drilled shafts," Journal of Geotechnical and Geoenvironmental Engineering, vol. 135, no. 6, pp. 778-789, 2009.

[16] X. Y. Bai, Y. Y. Mou, M. Y. Zhang et al., "Experimental study on bearing capacity of grouting after weathering large-diameter cast-in-place piles," Journal of Civil and Environmental Engineering (Chinese and English), vol. 41, no. 2, pp. 1-11, 2019.

[17] X.-Y. Chen, M.-Y. Zhang, and X.-Y. Bai, "Axial resistance of bored piles socketed into soft rock," KSCE Journal of Civil Engineering, vol. 23, no. 1, pp. 46-55, 2019.

[18] China Academy of Building Research, JGJ 94-2018 Technical Code for Building Pile foundations, China Architecture \& Building Press, Beijing, China, 2018. 
[19] China Academy of Building Research, JGJ 106-2014 Technical Code for Testing of Building Foundation piles, China Architecture \& Building Press, Beijing, China, 2014.

[20] Z. Wang and W. Richwien, "Displacement of a pile under axial load," Géotechnique, vol. 49, no. 4, pp. 537-541, 1999.

[21] M. Zhao, Y. Lei, and X. Liu, "Analysis of load transfer of rocksocketed piles based on characteristics of pile-rock structural plane," Chinese Journal of Rock Mechanics \& Engineering, vol. 28, no. 1, pp. 103-110, 2009.

[22] J. Li, Y. Tan, and F. Liang, "A modified analysis method for the nonlinear load transfer behaviour of axially loaded piles," KSCE Journal of Civil Engineering, vol. 16, no. 3, pp. 325-333, 2012.

[23] F. Liang, X. Liang, C. Wang, J. Wang, and Y. Li, "Influence of rigidity and load condition on the contact stress and settlement deformation of a spread foundation," Journal of Testing and Evaluation, vol. 47, no. 2, Article ID 20180290, 2019. 